\title{
Knowledge and Self-care of Patients Recently Diagnosed With Atrial Fibrillation
}

\author{
Rania Ali Ibrahim ${ }^{1}$, Assist prof. Neamat Allah Gomaa Ahmed ${ }^{2}$, \\ Assist prof. Amal Baker Abo El-Ata ${ }^{3}$ \\ (ICU Head nurse, Damietta general Hospital, Cairo, Egypt ${ }^{1}$ \\ (Medical - Surgical Nursing, Faculty of Nursing/ Ain Shams University, Egypt) ${ }^{2}$ \\ (Medical - Surgical Nursing, Faculty of Nursing / Port Said University, Egypt) ${ }^{3}$
}

\begin{abstract}
Background: Atrial Fibrillation (AF) is the most broadly recognized managed arrhythmia around the world. Identified knowledge and self-care to patients with AF is the way to successfully live with their disease. So necessary to this knowledge to be identified. This study aimed to assess knowledges and self-care of patients recently diagnosed with atrial fibrillation. A descriptive design was used in the current study. The study was conducted at intensive care unit and Cardiac care unit in El- zohor hospital, Port Said general hospital and El-tadamon hospital at Port Said city. A convenience sample of 110 patients recently diagnosed with atrial fibrillation included in this study. Tools of data collection, two tools were used for data collection; Patient's knowledge relevant information questionnaire and Patient's Self-care Scale. Results of the study revealed that, most of patients had moderate knowledges about atrial fibrillation and the level of self-care was observed to be high in male, highly percent among educated patients, in the individuals who work and live in urban areas. Knowledges was positive predictor of AF and self-care practice. Conclusion: most of studied patients had unsatisfactory knowledges and self-care about atrial fibrillation regarding themselves. The current study recommended that, Well-planned orientation, in-services training program and proper supervision of patients with atrial fibrillation is recommended.
\end{abstract}

Keywords: Atrial Fibrillation, Patient's knowledges, Self-Care practice 


\section{INTRODUCTION}

Atrial fibrillation (AF) is the most well-known maintained heart rhythm problem experienced in clinical practice and is a worldwide general Health problem. Beginning predominately from the left chamber, AF brings about disorganized atrial action showing clinically as a sporadic cardiovascular rate and heart output. In spite of good advance in the organization of patients with $\mathrm{AF}$, this arrhythmia remains one of the noteworthy explanations behind stroke, coronary diseases, abrupt and passing on the world. In addition, the amount of patients with AF is foreseen to rise steeply later on (Kirchhof et al., 2016).

When patients believe they have a good understanding of knowledge about AF they report fewer symptoms, perceive greater control over AF, and attribute less emotional distress to AF. When persons' knowledges deficits and educational knowledges are identified, resources can be tailored to bridge the knowledges gap. Specific interventions can be used to improve knowledges, self-care, and potentially improve health outcomes (Xu et al., 2010).

Personal satisfaction for individuals with constant conditions is subject to the individual's capacity to self-care with their condition, and not with the way that consistence to health counsel is normal, results can be variable. More established individuals may give comorbidities even in the intense setting, and a comprehension of unending consideration and self-administration support and systems will help health experts to assist them to keep sound (Hendrikx et al., 2016). Self-care includes the individuals with an unending condition working in association with their considerations and experts so they can arrange an arrangement of care and survey or screen the arrangement. Self-Care mediation and bolster mean to build up a man 's self-adequacy and helps the individual to doing in exercises that help the individual to detect and deal with the manifestations and indications of their condition (Gupta, Perera, \&Ganesan, 2013).

\section{Significance of the study:}

In 2010, the assessed quantities of patients with AF worldwide were 20.9 million and 12.6 million, More than 750,000 patients hospitalized every year in view of AF. The condition adds to an expected 130,000 passing every year. Appraisals propose an AF 
predominance of roughly $3 \%$ in grown-ups matured 20 years or more seasoned with more prominent commonness in more established people and in patients with conditions, for example, hypertension, heart disappointment, coronary course illness (CAD), valvular coronary illness, stoutness, or diabetes mellitus (Haim et al., 2015).

World health organization (WHO) assessed that the number of Individuals with AF in 2015 at Egypt was extrapolate 559,686 population estimated for 76,117,421 (World health organization, 2015). In addition, number of patients admitted to El-zohor, Port Said general and El-tadamon hospitals during the period of $2014-2015$ due to AF disease were 215 Patients according to (annual statistic of Port Said hospitals, 2015).

Nurses play a vital role with patients with AF, first identify the person's knowledges deficit about AF. Identifying knowledges level is a critical first step in improving health outcomes. Once a person's knowledges level is determined, his/her educational knowledges related to AF can also be identified, and resources can be developed to meet those knowledges (McCab et al., 2008).

\section{AIM OF STUDY:}

Assess knowledges and self-care of patients recently diagnosed with atrial fibrillation.

\section{Research Questions:}

To accomplish the aim of this study, the following research questions are planned:

A-What are the knowledges of patients recently diagnosed with atrial fibrillation?

B-What is self-care of patients recently diagnosed with atrial fibrillation?

\section{SUBJECTS AND METHOD:}

\section{Subjects}

\section{Research design:}

A descriptive (cross-sectional) design utilized in this study to satisfy the aim of the study and answer the research questions.

\section{Setting:}

This study was carried out in ICU and CCU at Port Said city governmental hospitals disturbed as following: - (Port Said general hospital, El-zohor hospital and El-tadamon hospital). 


\section{Subjects}

A convenience sample of (110) adult patients in ICU and CCU during the six months from the beginning of January, 2016, to the end of June 2016.

Inclusion criteria were Adult Patients (both sexes), Patient has AF for 6 months to one year, and all participants had at least one ECG-documented episodes of atrial fibrillation and Patients conscious and able to communicate.

Exclusion criteria were: Patient with Malignant tumor, and Patient with Physical or mental limitations.

Tools of data collection: Two tools were used in this study to collect the necessary data.

Tool I: Patients knowledges relevant information questionnaire; structured Interviewing Questionnaire was developed by the researcher after reviewing and utilizing the most recent and relevant literature (Kumar \& Clark, 2009; Smeltzer\& Bare, 2010), it was consisted of three parts:

Part 1: Was concerned with demographic characteristics of patients under study such as (age, gender, marital status, occupation, education level, and residence).

Part 2: This part was used to assess patient current diagnosis, duration of disease, present history, past history, family history, previous surgery, previous cardioversion or ablation, current medication and patient habits (nutritional, caffeine intake, smoking and exercise).

Part 3: Used to assess Patient knowledges, it composed of 39 questions in total and included four categories: knowledge about AF disease (3 items), causes, risk factor and symptoms (9 items), therapeutic strategies (5 items), anticoagulant (9 items) and selfmonitoring (13 items).

Scoring system for tool (I): All subjects' knowledge to respond (yes) or (no) to each question. A right answer was scored $=1$; an erroneous answer was scored $=0$. Scores of everything were summed up, and the aggregate score ran from 0 to 39. Score percentage $=$ mean score $/$ most extreme conceivable score $\times 100 \%$. Higher score showed more learning about atrial fibrillation. The level of knowledge was classified according to good, moderate and poor for overall knowledge and in each knowledge section. A score of 75\% = (30-39) were classified as (good), from $74 \%$ to $50 \%=(21-29)$ classified as (moderate), and a score $<50 \%=(0-20)$ was classified as (poor) (Tesha, 2006). 
Tool II: Patient's Self-care Scale; was developed by Jeroen et al., 2013) based on a standard questionnaire in Atrial Fibrillation to assess patient's self-care regarding, adherence to therapeutic regimen (11), international normalized ratio (INR) monitoring (2 items), periodic follow up (3 items), daily pulse self-examination (4 items), symptom management (10 items), and a healthy lifestyle (20items). The subjects were asked to rate each item to indicate the frequency which they performed the self-care practices.

Scoring system for tool (II) Items were scored on a 5-point scale ranging from 1(never) to 5(always). The self-care scores were divided into three levels: low, moderate and high. For the 50 item of the questionnaire, the points were added up ranging from 50 to 250 . Score percentage $=$ mean score $/$ maximum possible score $\times 100 \%$. A score of $75 \%=(188-250)$ were classified as (high), from $74 \%$ to $50 \%=(125-187)$ classified as (moderate), and a score $<50 \%=(50-125)$ was classified as (low). (Aliasgharpour et al., 2013).

\section{Method:}

\section{Ethical Considerations:}

Each patients was asked to give verbal consent to participate in the study after full explanation of the nature and the main aim of the study and it's expected out comes. Each participant was free to either participate or not in this study and had the right to withdraw from the study at any time without any rationale. The researcher assured voluntary participation, anonymity and confidentiality of the gathered data. These were assured through coding of all data.

\section{Content Validity:}

Content validity was tested by eleven experts from Faculty of Nursing in the field of Medical - Surgical Nursing. The questionnaire was modified according to the experts' comments and recommendations.

\section{Reliability:}

The tools tested for reliability. The internal consistency of tools has been tested using Cronbach's alpha coefficient (0.7).

\section{Pilot Study:}

A pilot study was done to survey the possibility and materialness of tools and to evaluate the best possible time required for answering the questionnaire. It was led on (11 
patients) $10 \%$ of patients from recently referenced chosen settings. The patients incorporated into the pilot study were prohibited from the main sample.

\section{Field of work:}

Data utilizing pre-constructed tool, it were gathered over a time of a half year from the earliest starting point of January to the end of June, 2016. Information were gathered for three days out of every week for every medical clinic (Saturday, Monday and Wednesday) at morning shift from 8:00 am to 2:00 pm and evening shifts from 2:00 pm to $8: 00 \mathrm{pm}$.

Data were gathered utilizing written questionnaire sheet for every patient that was talked with exclusively to fill in the survey sheet by the researcher which was perused the survey to the patients and as they addressed the specialist filled in the questionnaire. The all-time required for the utilization of the tool was lasted approximately around 20-30 minutes. The first tool was structured interviewing questionnaire; it keeps going around 20 minutes to fill in it while, the second tool was evaluated patients self-care it endures around 15-20 minutes to fill in it.

\section{Statistical Data Analysis (Kotz, Balakrishnan, Read, \&Vidakovic, 2006):}

Data were fed to the computer and analyzed using IBM SPSS software package version 20.0. (Armonk, NY: IBM Corp) (Kirkpatrick \& Feeney, 2013) Quantitative data were described using number and percent. Qualitative data were described using range (minimum and maximum), mean, standard deviation and median. Significance of the obtained results was judged at the 5\% level. The used tests were (Chi-square test, Monte Carlo correction, and Pearson coefficient.

\section{RESULTS:-}

The Results showed that, more than half of them (56.4\%) were females and studied patients age range from 50 to 60 years $(76.4 \%)$. Regarding to marital status, most of studied patients were married, and only about one third of patients were widow (34.5\%). Concerning occupation, one- third of studied patients $(32.7 \%)$ were a housewife, while the minority of them (13.6\%) was manual work. As regard to education level, more than one third of studied patients $(37.3 \%)$ were intermediate educational level. Regarding to residence, the most of studied patients $(95.5 \%)$ were lived in urban areas. Table (1). 
Regarding to the distribution of studied patients recently diagnosed with AF according to their total score of knowledges, Table 2 showed the domains' scores of correct reported responses of items related to AF knowledges. The total scores of knowledges about AF was $25.84 \pm 4.63$ (ranged from $13.0-43.0$ ). The most of participants at fair level in Selfmonitoring and Detection and recurrence score, About AF disease score and Anticoagulant score were at poor level and therapeutic strategies scores were at good level.

In relation to knowledge level were classified into three level (poor, fair and good) in the studied group $80.0 \%$ had fair level and only $6.4 \%$ had good level. (fig 1 ).

Regarding to relation between overall knowledges and demographic characteristics for patient recently diagnosed with AF. There were no statistically significant difference in mean AF knowledge scores between males and females $\left(\mathrm{x} 2=6.498^{*}, \mathrm{p}=0.038^{*}\right)$, married and unmarried $(\mathrm{x} 2=4.759, \mathrm{p}=0.089)$. the mean AF scores of the subjects in the highest educations groups were significantly higher than those of the subjects in the lowest educations groups $\left(\mathrm{x} 2=28.911^{*}, \mathrm{p}=<0.001^{*}\right)$, middle age and young adults had significantly higher knowledge scores than older adults $(\mathrm{x} 2=5.655, \mathrm{p}=0.403)$, subjects who lived in urban areas had higher knowledge than those lived in rural areas $(\mathrm{x} 2=$ $\left.12.022^{*}, \mathrm{p}=0.002 *\right)$, subjects who work had higher knowledge score than who didn't work $\left(\mathrm{x} 2=17.109^{*}, \mathrm{p}=0.002^{*}\right) .($ Table 3$)$.

Concerning with the Average total score of different items of self-Care among studied patients recently diagnosed with $\mathrm{AF}$, it observed that, the total score of self-Care was $132.96 \pm 9.19$ (ranged from $113.0-167.0$ ). The total self-Care score and for all selfCare dimensions were all at moderate level except pulse self-examination at low level. (Table 4).

Concerning with correlation between overall self-Care behavior and demographic characteristics among studied patients recently diagnosed with AF, There were no statistically significant difference in mean AF self-Care scores between middle age, young adults and older adults $(\mathrm{x} 2=3.684, \mathrm{p}=0.764)$, married and unmarried $(\mathrm{x} 2=$ 0.893, $\mathrm{p}=0.846$ ). The mean self-Care scores of the subjects in the males were 
significantly higher females $(\mathrm{x} 2=2.327, \mathrm{p}=0.323)$, the mean self-Care scores of the subjects in the highest educations groups were significantly higher than those of the subjects in the lowest educations groups $(\mathrm{x} 2=4.588, \mathrm{p}=0.556)$, subjects who lived in urban areas had higher knowledge than those lived in rural areas $(x 2=3.785, \mathrm{p}=0.285)$, subjects who work had higher knowledge score than who didn't work $(\mathrm{x} 2=4.695, \mathrm{p}=$ 0.551). (table 5)

In relation to the distribution of studied patients recently diagnosed with AF according to self-Care levels. Self-Care levels were classified into three level (low, moderate and high) in the studied group (93.6) had moderate Self-Care level, (4.5) had low Self-Care level and only (1.8) had high Self-Care level. (fig 2).

Regarding to relation between overall self-Care among studied patients recently diagnosed with AF and overall knowledge for patient. The dependent variables was the total scores of the practice and the independents variables were the knowledge scores. The results demonstrates that knowledge $\left(\mathrm{r}=0.344^{*}, \mathrm{p}=<0.001 *\right)$ more positive predictor of AF self-Care. (table 6)

Table (1): Demographic characteristics among studied patients recently diagnosed with AF.

\begin{tabular}{|c|c|c|c|}
\hline \multirow{2}{*}{\multicolumn{2}{|c|}{ Personal characteristics }} & \multicolumn{2}{|c|}{$(n=110)$} \\
\hline & & \multirow{2}{*}{$\begin{array}{l}\text { No } \\
62 \\
\end{array}$} & \multirow{2}{*}{$\begin{array}{c}\% \\
56.4\end{array}$} \\
\hline $\mathbf{S}_{-}$ & Female & & \\
\hline Sex & Male & 48 & 43.6 \\
\hline \multirow{3}{*}{ Age } & $30<40$ years & 9 & 8.2 \\
\hline & $40<50$ years & 17 & 15.5 \\
\hline & $50-\leq 60$ years & 84 & 76.4 \\
\hline \multirow{4}{*}{ Education level } & Illiterate & 9 & 8.2 \\
\hline & Read and write & 39 & 35.5 \\
\hline & Intermediate School & 41 & 37.3 \\
\hline & University Degree & 21 & 19.1 \\
\hline \multirow{4}{*}{ Occupation } & Officer (Employed) & 32 & 29.1 \\
\hline & Manual work & 15 & 13.6 \\
\hline & Retired & 27 & 24.5 \\
\hline & Housewife & 36 & 32.7 \\
\hline \multirow{2}{*}{ Marital status } & Married & 72 & 65.5 \\
\hline & Widower & 38 & 34.5 \\
\hline \multirow[t]{2}{*}{ Treatment System } & Governmental & 55 & 50.0 \\
\hline & Health insurance & 55 & 50.0 \\
\hline \multirow{2}{*}{ Residence } & Rural & 5 & 4.5 \\
\hline & Urban & 105 & 95.5 \\
\hline
\end{tabular}


Table( 2): frequency percentage distribution of studied patients recently diagnosed with AF according to their total score of knowledge $(n=110)$

\begin{tabular}{|c|c|c|c|}
\hline Total score & Min. - Max. & Mean \pm SD & Median \\
\hline About AF disease score & $0.0-3.0$ & $1.47 \pm 0.67$ & 1.0 \\
\hline Detection \&recurrence score & $4.0-9.0$ & $5.42 \pm 0.89$ & 5.0 \\
\hline Therapeutic strategies score & $3.0-8.0$ & $5.98 \pm 1.32$ & 6.0 \\
\hline Anticoagulant score & $1.0-9.0$ & $4.51 \pm 1.58$ & 4.0 \\
\hline Self-monitoring & $2.0-15.0$ & $8.45 \pm 2.24$ & 8.50 \\
\hline Overall & $13.0-43.0$ & $25.84 \pm 4.63$ & 26.0 \\
\hline
\end{tabular}

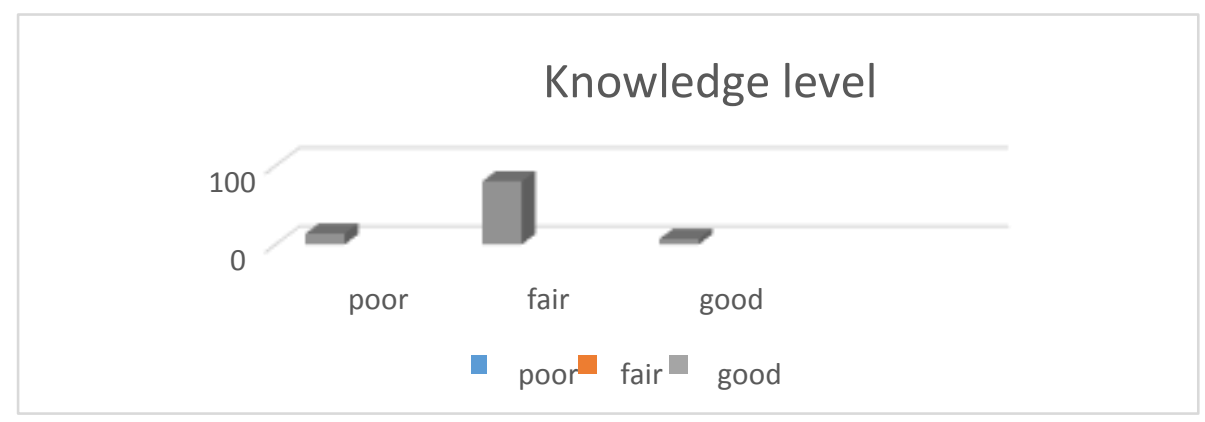

Figure (1): Distribution of the studied patients recently diagnosed with AF according to their knowledge 
Table (3): Correlation between overall knowledge and Demographic characteristics for studied patient recently diagnosed with Atrial Fibrillation $(n=110)$

\begin{tabular}{|c|c|c|c|c|c|c|c|c|}
\hline \multirow{3}{*}{$\begin{array}{l}\text { Demographic } \\
\text { characteristic }\end{array}$} & \multicolumn{6}{|c|}{ Overall knowledge } & \multirow{3}{*}{$\chi^{2}$} & \multirow{3}{*}{ MCp } \\
\hline & \multicolumn{2}{|c|}{$\begin{array}{c}\text { Poor- low }(\mathbf{n}= \\
15)\end{array}$} & \multicolumn{2}{|c|}{$\begin{array}{c}\text { Fair- moderate }(\mathbf{n}= \\
\mathbf{8 8})\end{array}$} & \multicolumn{2}{|c|}{ Good-high $(n=7)$} & & \\
\hline & No. & $\%$ & No. & $\%$ & No. & $\%$ & & \\
\hline \multicolumn{9}{|l|}{ Gender } \\
\hline Male & 4 & 26.7 & 38 & 43.2 & 6 & 85.7 & \multirow{2}{*}{$6.498 *$} & \multirow{2}{*}{ 0.038* } \\
\hline Female & 11 & 73.3 & $\mathbf{5 0}$ & 56.8 & 1 & 14.3 & & \\
\hline \multirow[t]{2}{*}{ Age group $30-<40$} & & & & & & & \multirow{4}{*}{5.655} & \multirow{4}{*}{0.403} \\
\hline & $\mathbf{0}$ & 0.0 & 8 & 9.1 & 1 & 14.3 & & \\
\hline $40-<50$ & 1 & 6.7 & 14 & 15.9 & 2 & 28.6 & & \\
\hline $50-\geq 60$ & 3 & 20.0 & 26 & 29.5 & 1 & 42.9 & & \\
\hline \multicolumn{9}{|l|}{ Marital status } \\
\hline Married & 6 & 40.0 & 61 & 69.3 & 5 & 71.4 & \multirow{2}{*}{4.759} & \multirow{2}{*}{0.089} \\
\hline Widow & 9 & 60.0 & 27 & 30.7 & 2 & 28.6 & & \\
\hline \multicolumn{9}{|l|}{ Educational level } \\
\hline Illiterate & 5 & 33.3 & 4 & 4.5 & $\mathbf{0}$ & 0.0 & \multirow{4}{*}{ 28.911* } & \multirow{4}{*}{$<0.001 *$} \\
\hline Read \& write & 9 & 60.0 & 30 & 34.143 .2 & $\mathbf{0}$ & 0.0 & & \\
\hline Moderate education & 1 & 6.7 & 38 & & 2 & 28.6 & & \\
\hline University & $\mathbf{0}$ & 0.0 & 16 & 18.2 & 5 & 71.4 & & \\
\hline \multicolumn{9}{|l|}{ Working status Office } \\
\hline Work & $\mathbf{0}$ & 0.0 & 29 & 33.0 & 3 & 42.9 & \multirow{4}{*}{$17.109 *$} & \multirow{4}{*}{$0.002 *$} \\
\hline Manual Work & 2 & 13.3 & 13 & 14.8 & $\mathbf{0}$ & 0.0 & & \\
\hline Retired & 3 & 20.0 & 20 & 22.7 & 4 & 57.1 & & \\
\hline House wife & 10 & 66.7 & 26 & 29.5 & $\mathbf{0}$ & 0.0 & & \\
\hline \multicolumn{9}{|l|}{ Treatment Coverage } \\
\hline Governmental & 14 & 93.3 & 41 & 46.6 & $\mathbf{0}$ & $\mathbf{0 . 0}$ & \multirow[t]{2}{*}{ 19.931* } & \multirow{2}{*}{$<0.001 *$} \\
\hline Health insurance & 1 & 6.7 & 47 & 53.4 & 7 & 100.0 & & \\
\hline \multicolumn{9}{|l|}{ Residence Rural } \\
\hline Urban & 4 & 26.7 & 1 & 1.1 & $\mathbf{0}$ & 0.0 & \multirow{2}{*}{$12.022 *$} & \multirow[t]{2}{*}{$0.002 *$} \\
\hline & 11 & 73.3 & 87 & 98.9 & 7 & 100.0 & & \\
\hline
\end{tabular}

2: Chi square test -MCp: $p$ value for Monte Carlo for Chi square test *: Ss at $\mathbf{p} \leq \mathbf{0 . 0 5}$ 
Table (4): Average total score of different items of self-care practice among studied patients recently diagnosed with $\mathrm{AF}$

\begin{tabular}{|c|c|c|c|}
\hline Self-care items & Min. - Max. & Mean \pm SD & Median \\
\hline Adherence to medication & $30.0-49.0$ & $38.28 \pm 3.37$ & 39.0 \\
\hline INR monitoring & $8.0-10.0$ & $9.05 \pm 0.99$ & 10.0 \\
\hline Follow up & $8.0-13.0$ & $10.25 \pm 1.17$ & 10.50 \\
\hline Pulse self-examination & $4.0-14.0$ & $5.02 \pm 2.09$ & 4.0 \\
\hline Healthy lifestyle & $35.0-64.0$ & $51.61 \pm 4.54$ & 52.0 \\
\hline Symptom management & $14.0-24.0$ & $18.65 \pm 2.19$ & 18.0 \\
\hline Overall & $113.0-167.0$ & $132.96 \pm 9.19$ & 132.0 \\
\hline
\end{tabular}

Table (5): Correlation between overall self-Care practice and Demographic

Characteristics among studied patients recently diagnosed with Atrial Fibrillation $(n=110)$

\begin{tabular}{|c|c|c|c|c|c|c|c|c|}
\hline & \multicolumn{6}{|c|}{ Overall self- Care among studied AF patients } & \multirow{3}{*}{$\chi^{2}$} & \multirow{3}{*}{ MCp } \\
\hline & \multicolumn{2}{|c|}{ Poor $(n=5)$} & \multicolumn{2}{|c|}{ Fair $(n=103)$} & \multicolumn{2}{|c|}{ Good $(n=2)$} & & \\
\hline & No. & $\%$ & No. & $\%$ & No. & $\%$ & & \\
\hline $\begin{array}{c}\text { Gender } \\
\text { Male } \\
\text { Female }\end{array}$ & $\begin{array}{l}2 \\
3\end{array}$ & $\begin{array}{l}40.0 \\
60.0\end{array}$ & $\begin{array}{l}44 \\
59\end{array}$ & $\begin{array}{l}42.7 \\
57.3\end{array}$ & $\begin{array}{l}2 \\
0\end{array}$ & $\begin{array}{c}100.0 \\
0.0\end{array}$ & 2.327 & 0.323 \\
\hline $\begin{array}{c}\text { Age group } 30-<40 \\
\begin{array}{c}\mathbf{4 0}-<\mathbf{5 0} \\
\mathbf{5 0}-\geq \mathbf{6 0}\end{array}\end{array}$ & $\begin{array}{l}0 \\
1 \\
2\end{array}$ & $\begin{array}{c}0.0 \\
20.0 \\
40.0\end{array}$ & $\begin{array}{c}9 \\
15 \\
28\end{array}$ & $\begin{array}{c}8.7 \\
14.6 \\
27.2\end{array}$ & $\begin{array}{l}0 \\
1 \\
0\end{array}$ & $\begin{array}{c}0.0 \\
50.0 \\
50.0\end{array}$ & 3.684 & 0.764 \\
\hline $\begin{array}{c}\text { Marital status } \\
\text { Married } \\
\text { Widow }\end{array}$ & $\begin{array}{l}3 \\
2 \\
\end{array}$ & $\begin{array}{l}60.0 \\
40.0\end{array}$ & $\begin{array}{l}67 \\
36\end{array}$ & $\begin{array}{l}65.0 \\
35.0 \\
\end{array}$ & $\begin{array}{l}2 \\
0\end{array}$ & $\begin{array}{c}100.0 \\
0.0\end{array}$ & 0.893 & 0.846 \\
\hline $\begin{array}{c}\text { Educational level } \\
\text { Illiterate } \\
\text { Read \& write } \\
\text { Moderate } \\
\text { education } \\
\text { University }\end{array}$ & $\begin{array}{l}1 \\
1 \\
2 \\
1\end{array}$ & $\begin{array}{l}20.0 \\
20.0 \\
40.0 \\
\\
20.0\end{array}$ & $\begin{array}{c}8 \\
37 \\
39 \\
19\end{array}$ & $\begin{array}{c}7.8 \\
35.9 \\
37.9 \\
\\
18.4\end{array}$ & $\begin{array}{l}0 \\
1 \\
0 \\
1\end{array}$ & $\begin{array}{c}0.0 \\
50.0 \\
0.0 \\
\\
50.0\end{array}$ & 4.588 & 0.556 \\
\hline $\begin{array}{c}\text { Working status } \\
\text { Office Work } \\
\text { Manual Work } \\
\text { Retired } \\
\text { House wife }\end{array}$ & $\begin{array}{l}2 \\
0 \\
2 \\
1\end{array}$ & $\begin{array}{c}40.0 \\
0.0 \\
40.0 \\
20.0\end{array}$ & $\begin{array}{l}29 \\
14 \\
25 \\
35\end{array}$ & $\begin{array}{l}28.2 \\
13.6 \\
24.3 \\
34.0\end{array}$ & $\begin{array}{l}1 \\
1 \\
0 \\
0\end{array}$ & $\begin{array}{c}50.0 \\
50.0 \\
0.0 \\
0.0\end{array}$ & 4.695 & 0.551 \\
\hline $\begin{array}{c}\text { Treatment } \\
\text { coverage } \\
\text { Governmental } \\
\text { Health insurance }\end{array}$ & $\begin{array}{l}2 \\
3\end{array}$ & $\begin{array}{l}40.0 \\
60.0\end{array}$ & $\begin{array}{l}52 \\
51\end{array}$ & $\begin{array}{l}50.5 \\
49.5\end{array}$ & $\begin{array}{l}1 \\
1\end{array}$ & $\begin{array}{l}50.0 \\
50.0\end{array}$ & 0.517 & 1.000 \\
\hline $\begin{array}{l}\text { Residence Rural } \\
\text { Urban }\end{array}$ & $\begin{array}{l}1 \\
4\end{array}$ & $\begin{array}{l}20.0 \\
80.0\end{array}$ & $\begin{array}{c}4 \\
99\end{array}$ & $\begin{array}{c}3.9 \\
96.1\end{array}$ & $\begin{array}{l}0 \\
2\end{array}$ & $\begin{array}{c}0.0 \\
100.0\end{array}$ & 3.785 & 0.285 \\
\hline
\end{tabular}




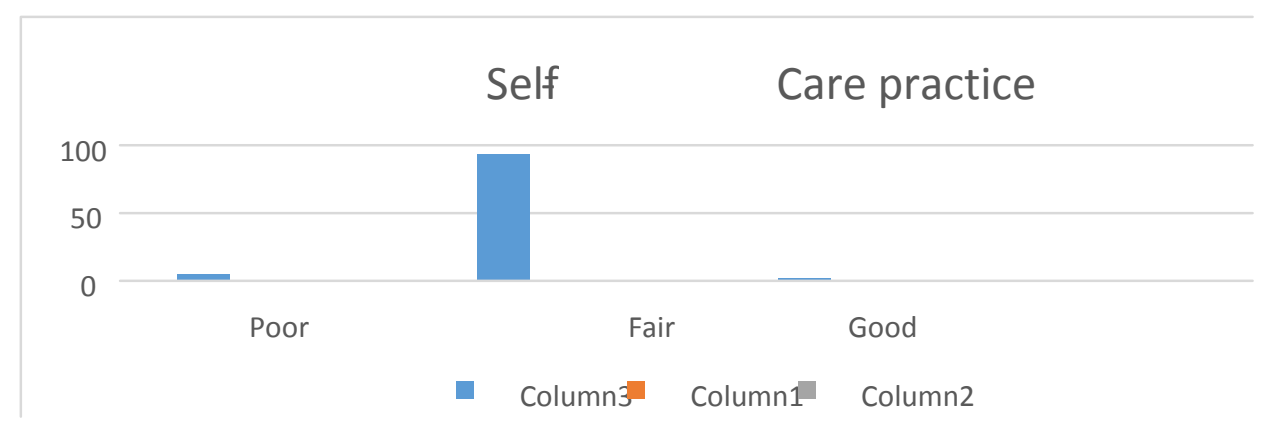

Figure (2) distribution of studied patients recently diagnosed with AF according to selfcare levels.

Table (6): Relation between overall self-Care practice among studied patients recently diagnosed with Atrial Fibrillation and overall knowledge for patient $(n=110)$

\begin{tabular}{|c|c|c|c|c|c|c|c|c|}
\hline & \multicolumn{6}{|c|}{ Overall self-Care among studied AF patients } & \multirow{3}{*}{$\chi^{2}$} & \multirow{3}{*}{ MCp } \\
\hline & \multicolumn{2}{|c|}{ Poor $(n=5)$} & \multicolumn{2}{|c|}{ Fair $(n=103)$} & \multicolumn{2}{|c|}{$\begin{array}{l}\text { Good } \\
(n=2)\end{array}$} & & \\
\hline & No. & $\%$ & No. & $\%$ & No. & $\%$ & & \\
\hline Overall knowledge & & & & & & & & \\
\hline Poor (low) & 1 & 20.0 & 14 & 13.6 & $\mathbf{0}$ & 0.0 & & \\
\hline Fair (moderate) & 3 & 60.0 & 84 & 81.6 & 1 & $\mathbf{5 0 . 0}$ & 7.583 & 0.082 \\
\hline Good (high) & 1 & 20.0 & 5 & 4.9 & 1 & $\mathbf{5 0 . 0}$ & & \\
\hline Overall knowledge & & & & & & & & \\
\hline Satisfactory $(\geq 75 \%)$ & 4 & 80.0 & 98 & 95.1 & $\mathbf{1}$ & $\mathbf{5 0 . 0}$ & 6.914 & 0.068 \\
\hline Un satisfactory $(<75 \%)$ & 1 & 20.0 & 5 & 4.9 & 1 & $\mathbf{5 0 . 0}$ & & \\
\hline
\end{tabular}

$\square$ 2: Chi square test

MCp: $p$ value for Monte Carlo for Chi square test

\section{DISCUSSION:}

The current study aimed to assess knowledge and self-care of patients recently diagnosed with atrial fibrillation and conducted at intensive care unit and Cardiac care unit in Elzohor hospital, Port Said general hospital and El-tadamon hospitals, at Port Said city. As regard to age, the majority of patient's age ranged from fifty to sixty years old. This may be due to normal physiological changes associated with ageing process. This finding agreement with study conducted in six Middle East countries support the previous 
findings where mean age of patients with AF was fifty seven years (Zubaid, et al., 2011). As regard sex, females were more prevalent than males, This finding come in agreement with a study conducted in Daqahlya governorate which report that female often develop AF more than male (El-Zeky, 2014).This result is in contrast with studies conducted by (Martin, Pogoryelova, Koref, Bourke, \&Teare, 2014).

Factor Affecting Knowledges Level, as regard age, it was found that the younger in age more knowledge and the difference was statistically significant. On the same line other studies conducted at Brazil and Ethiopia revealed that knowledge mean scores of the youngest subjects were significantly higher compared with the very old group ( Feleke, Almayehu, \&Adane, 2013). Regarding sex, no statistically significant difference was found between knowledge of studied AF patients and sex. However, it was observed that males had higher knowledge scores than female. This may be due to increase the illiteracy among females than males, that accordance to study conducted by the Central Agency for Public mobilization and Statistics (CAPMAS, 2012). Other study conducted at Daqahlya governorate which reported that females were least knowledge about AF and coagulants therapy than males (El-Zeky, 2014).

Regarding of social state the study finding revealed statistically significant differences in mean AF knowledge scores between married and unmarried. This finding may have resulted from the priority among unmarried group which directed to themselves. This result is in accordance with other studies conducted by (Hongyan, et al., 2018) which revealed significant statistical difference among the knowledge level of respondents based on marital status. This result is in contrast with other studies conducted by (Eugene \& Bourne, 2013) which revealed no significant statistical difference among the knowledge level.

Concerning to the education levels the patient who higher level of education had reported more knowledge about AF compared to those with low education level and the difference was significant. This result is in agreement with other studies conducted at Daqahlya governorate by (El-Zeky, 2014) which reported that the more educated the study subject the more he or she had good knowledge. Regarding to occupation the results of this study revealed that patients who work report higher knowledge about AF. In contrast to housewives and the difference was statistically significant. In accordance 
other study conducted by (Ghisi et al., 2013) among atrial fibrillation patients reported significant correlation between occupation and knowledge.

In relation to residence results of this study revealed that patients who lived in urban areas had higher knowledge scores than those lived in rural areas and the difference was statistically significant, this may be due to poor living conditions in rural areas. This is congruent with a study conducted at Dakahlya governorate by (El-Zeky, 2014). In contrast another study conducted at Egypt among AF patients reported no significant relation between knowledge level and occupation (Hassan, 2009).

Factors affecting knowledges: Firstly, in the present study one third of patients were aware of the AF disease. This may be due to shortage of nurse's staff and lack of effective communication. This results agree with a study conducted in Daqahlya governorate which revealed that fewer than half of the patients were able to aware of the AF disease(El-Zeky, 2014).Another study conducted at Hong Kong also reported that none of patients were aware that their cardiac condition called AF(Lee, Reyes, McManus, Maitas, \& Chon, 2013).

Second, most of patients reported that they know therapeutic strategies for AF and purpose of AF therapeutic strategies. This is in accordance with other Studies suggest where patients have a greater knowledge of anticoagulant therapy, international normalized ratio (INR) values are more often within target range (Tang, \& Lee, 2003)

Third, in the present study about less than half of patients were aware of anticoagulant therapy, which one quarters the patients can distinguish between different dosage forms by color. This is in accordance to studies conducted at Malaysia by (Cabral, Ansel, \&Hylek, 2011) who indicated that approximately two-third of respondents had poor knowledge of different tablet dosage forms. In contrast this finding another study conducted at Daqahlya governorate which reported that three quarter of patients can distinguish between different dosage forms by color. Regarding the most of patients know that anticoagulants may cause bleeding. This study finding is in agreement with results of other studies conducted in Finland reported that more than four fifths know that anticoagulant agents increase the risk of bleeding (Koponen et al., 2007).In contrast another study conducted at Daqahlya governorate which reported that more than half of patients were not aware of bleeding risk associated with anticoagulants. 
Fourth, in relation to self-monitoring, about more than half of patients were aware of self-monitoring, in the present study the majority of patients know that INR is a test for blood clotting but the most of patients reported that they know purpose of monitoring INR and only the necessary to monitor INR. On the same line with another study conducted by (El-Zeky, 2014) in Daqahlya governorate. In contrast other studies conducted in Jordan by (Yassien et al., 2012) which report that less than one third of patients know purpose of monitoring INR. In addition also in the present study reported that majority of patients lack knowledge about target INR and the current value of INR. This is in accordance with another study conducted at Daqahlya governorate (El-Zeky, 2014) which reported that majority of patients lack knowledge about target INR and current value of INR.

Reported self-care and factors affecting self-care: The finding of this investigation demonstrated that the all-out mean score and every one of the elements of self-care practices among the subjects were at the moderate level with the exception of pulse selfassessment were at low level. This may be related to that only $6.8 \%$ of patients in later study were illiterate. This is in accordance with a study conducted at Daqahlya governorate by (El-Zeky, 2014).

Firstly, adherence to medication in the present study about two thirds of patients reported that they often or always take medication as many times per day as prescribed by doctor. This results is in accordance with study conducted at Jordan (Naddaf, 2004). This may be due to the fact that all patients in our study had insurance or governmental system and they receive medication for free.

Second, regarding to INR monitoring the majority of patients reported that more than half of patients reported that often or always able to have INR monitored on the requested dates and reported that they often or always discuss with their doctor the result of INR. This result is in accordance with another study conducted at china which reported that less than half of patients were not able to have INR monitored in the requested dates $(\mathrm{Xu}$ et al., 2010).In contrast another study conducted at USA reported that all patients keep INR appointments (McCabe, Schad, Hampton, \& Holland, 2008).

Third, in the present study about more than half of patients were aware of follow-up, which half of patients reported that they often or always able to attend regular follow-up 
on the requested dates. This result is in accordance with another study conducted at Daqahlya governorate by (El-Zeky, 2014).

Fourth, regarding pulse self-examinations, which in the present study two third of patients reported that they never or seldom check their pulse daily. This may be due to lack of knowledge of importance or feel it was unnecessary to monitor their pulse. On the same line another study conducted at china reported that about tow third of patients never or rarely measure their pulse (Xu et al., 2010).In contrast another study conducted at USA reported that about two third of patients measure their pulse daily. (McCabe et al., 2008).

Fifth, in relation to healthy lifestyle, more than half of patients unaware of the healthy lifestyle, in which the majority of studied patients reported drinking tea or coffee. The same findings was reported in other studies conducted by (Klatsky, Hasan, Armstrong, Udaltsova, \& Morton, 2011) in north California. As regard physical exercise, most of patients reported that they didn't do any form of physical exercise. This may be the most common symptoms reported by patients were palpitation and dyspnea. This in accordance with other studies done by (Smith et al., 2010) who reported that only third of AF patients doing exercise normally during AF. In contrast other studies done by (Xu et al., 2010) revealed that more than half of patients do appropriate exercise due according to the AF condition.

Concerning smoking, only minority of patients are still smokers, This study is in the same line with other studies conducted in china by (Xu et al., 2010), other study conducted in Bangladesh by (Akhter, 2010) who reported that the minority of patients are still smokers.

As regards sex there were statistically significant differences in mean self-care scores between male and female. The mean self-care scores in males were significantly higher than females. This result is in accordance with other studies conducted at Daqahlya governorate by (El-Zeky, 2014). Regardless of social state the study findings revealed no statistically significant differences in mean self-care scores between married and unmarried. On the same line other studies conducted at Jamaica revealed no significant difference among the marital status for self-care (Eugene \& Bourne, 2013). The result of the present study revealed that there was no significant difference between age of the 
studied subjects and their practicing of self-care practice. On the same line another studies conducted at Daqahlya governorate reported no statistical difference among selfcare managements practices index by age group of respondents (El-Zeky, 2014).In contrast other study conducted at Bangladesh and Muhimbili reported that middle age and young adults had higher self-care behaviors compared to older people(Akhter, 2010; Joho, 2012).

\section{CONCLUSION:}

The mean total knowledges score and its related regions were at moderate level with the exception of anticoagulant score were at mild level and remedial systems were at high level.

The level of knowledge and self-care were observed to be high in the young age than the old age, in males than females, in those with more elevated amount of instruction than those with bring down training, in the individuals who work than the individuals who didn't work and in the individuals who live in urban than those live in rural areas. The level of learning didn't vary in light of term being determined to have AF and economic health.

The mean score and all the measurement of self-care practice among the patients were at the direct level were at the direct level aside from beat self-examination were at mild level.

There was a solid positive connection between level of patient's knowledge about AF and self-care practices. Learning was certain indicator of a self-care conduct.

\section{RECOMMENDATION:}

\section{In view of the finding of the present examination, the accompanying proposals were recommended:}

1. Organizing patient's focused workshop to educate about atrial fibrillation and to improve patient's inspiration to assume a functioning part in their treatment.

2. Replication of the examination utilizing a bigger number of test and different setting in Egypt with the incorporation of control gathering to inspect the adequacy of instructive program for $\mathrm{AF}$ patients to improve their conditions, anticoagulation treatment and to advance self-care level.

3. Development of conducted instructive program for patients with $\mathrm{AF}$ and concentrate its impact on Patients personal satisfaction. 
4. Further research should appraisal for knowledges of AF patients in Egypt, which it is a little

5. It is encouraged to direct test studies in the preparation programs for the restorative staff about knowledges rules of AF patients.

\section{Acknowledgement}

Researchers might want to thank all the staff in the basic consideration units in the chose clinics and all patients who took an interest in this examination.

\section{REFERENCES:-}

Akhter N. (2010). Self-management among Patients with hypertension in Bangladesh. Master thesis. Prince of Songkla University, Bangladesh.

Available at: kb.psu.ac.th/psukb/bitstream/2010/8492/1/340992. Accessed in October, 2017.

Aliasgharpour M., Nageri ND., Yadegary MA., \& Haghani A. (2013). Effeact of an educational program on self-managements in patients with epilepsy. Journal of British epilepsy association; 22(1): pp. 4852.

Annual statistics of port said general, El-Tadamon and El-zohor hospitals at Port Said city, (2015), Accessed in Jun, 2016.

Cabral K.P., Ansell J., Hylek E.M. (2011). Future directions of stroke prevention in atrial fibrillation: the potential impact of noval anticoagulants and stroke risk stratification. J thrombllaemost; 9: pp. 441-9. Available at: https://www.ncbi.nlm.nih.gov/pubmed/21176102. Accessed in Jun, 2017.

Central Agency for Public Mobilisation and Statistic (CAPMAS). (2012). Available at http//website. Informer. Com / capmas.gov.eg accessed may 2017.

Elzkey M.E. (2014). Assessment of knowledgese and self-management behavior among patients with chronic Atrial Fibrillation. Master thesis, faculty of nursing, Mansoura University. Available at http://srv4.eulc.edu.eg/eulc_v5/Libraries/Thesis/BrowseThesisPages.aspx?fn=The

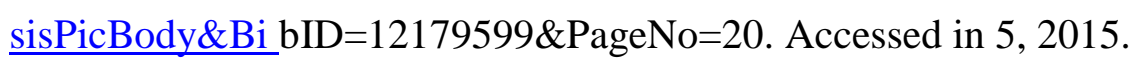


Eugene V., Bourne P.A. (2013). Hypertensive patient knowledgese, self-care management practices and challenges. J Behav Health; 2(3): pp. 259-268. Available at: $\underline{w w w . s c o p e m e d . o r g / ? m n o=26945}$. Accessed in 6, 2016.

Feleke S.A., Almayehu C.M., Adane H.T. (2013). Assessment of the level and associated factors with knowledgese and practice of diabetes mellitus among patients attending at Felege $\mathrm{Hi}$ wot Hospital. Northwest Ethiopia. Clinical Medicine Research; 2(6): 110-120. pp. Available at: https://pdfs.semanticscholar.org/.../e93245475c36ea426bec1b7d549. Accessed in 8, 2017.

Ghisi G.L., Thomas P., Benetti M. (2013). Assessment of patient knowledgese of cardiac rehabilitation: Brazil vs Canada. Arq Bras Cardiol; 101(3): pp. 255-262. Available at: https://www.ncbi.nlm.nih.gov/pmc/articles/PMC4032306/. Accessed in7, 2017.

Gupta A., Perera T., Ganesan A. (2013). Complications of catheter ablation of atrial fibrillation: a systematic review. CircArrhythmElectrophysiol.; 6 (6): pp. 10821088. Available at: https://www.ncbi.nlm.nih.gov/pubmed/24243785. Accessed in $5,2018$.

Haim M., Hoshen M., Reges O., Rabi Y., Balicer R., Leibowitz M. (2015). Prospectivenationalstudyof the prevalence, incidence, management and outcome of a large contemporary cohort of patients with incident non-valvular atrial fibrillation. J Am Heart Assoc; 4: p. 001486. Available at: https://www.ncbi.nlm.nih.gov/pubmed/25609415. Accessed in 3, 2017.

Hassan B.G. (2009). Factors affecting compliance of diabetic patient toward therapeutic management. Master thesis. Faculty of nursing Zagazig University. Available at: erepository.cu.edu.eg/index.php/MJCU/article/view/732/714. Accessed in February5, 2018.

Hendrikx T., Rosenqvist M., Sandstrom H., Persson M., Hornsten R. (2016). Identification of Paroxysmal, transient arrhythmias: Intermittent registration more 
efficient than the 24-hour Holter monitoring. Lakartidningen. 112. Available at: https://www.ncbi.nlm.nih.gov/pubmed/25584602. Accessed in 8, 2016.

Hongyan Liu., XianglongXu., Dengyuan Liu., YunshuangRao., Cesar Reis., Manoj Sharma., Jun Yuan., Yao Chen., andYong Zhao. (2018). Nutrition-Related Knowledgese, Attitudes, and Practices (KAP) among Kindergarten Teachers in Chongqing, China Available at: https://www.ncbi.nlm.nih.gov/pmc/articles/PMC5923657. Accessed in May8, 2018.

Jeroen M Hendriks, Harry J Crijns, Robert G Tieleman, Hubertus J, wrijhoef (2013). Int J Cardiol: doi:10.1016/j.ij card. 2012. pp. 12.047 (2013).

Joho A. (2012). Factor Affecting Treatment Compliance among Hypertension Patients In three District Hospitals - Dar Es-Salaam. Msc Nursing (Critical Care and Truma) Dissertation. Muhimbili University of Health and Allied Sciences. Available at: ihi.eprints.org/1584/1/Angelina_Alphonce_Joho. Accessed in Jun 8, 2017.

Kirchhof P., Benussi S., Kotecha D., Ahlsson A., Atar D., Casadei B., (2016). 2016 ESC Guidelines for the management of atrial fibrillation developed in collaboration with EACTS. Eur. Heart $\quad$ J. 37(38): $\quad$ pp. 2893-2962. doi:10.1093/eurheartj/ehw210.

Availableat:https://academic.oup.com/eurheartj/article/37/38/2893/2334964.accessed in may8, 2017.

Kirkpatrick LA., Feeney BC (2013). A simple guide to IBM SPSS statistics for version 20.0. Student ed. Belmont, Calif.: Wadsworth, Cengage Learning; Int J Cardiol: doi:10.1016/j.ij card. 2012. pp. 12.047 (2013).

Klatsky A.L., Hasan A.S., Armstrong M.A., Udaltsova N., Morton C. (2011). Coffee, caffeine and risk of hospitalization for arrhythmia. Perm J; 15(3): pp. 19-25. Available at:

https://www.ncbi.nlm.nih.gov/pubmed/22058665. Accessed in April8, 2017. 
Koponen, L., Rekola, L., Ruotsalainen, T., Lehto, M., Leino-Kilpi, H., Voipio-Pulkki, L.M. (2007, July): Patient knowledgese of atrial fibrillation: 3-month follow-up after an emergency room visit. Journal of Advanced Nursing. 2007 July; 61(1): pp. 51-61. Available at: https://www.ncbi.nlm.nih.gov/pubmed/18173735.Accessed in Jun 6, 2017.

Kotz S., Balakrishnan N., Read CB.,Vidakovic B (2006). Encyclopedia of statistical sciences. 2nd ed. Hoboken, N.J.: Wiley-Interscience; 2006. Available at: https://www.ncbi.nlm.nih.gov/pubmed/25193873. Accessed in May, 2016.

Kumar D., Clark M. (2009). Kumar \& Clark's Clinical Medicine.10thEd. London; Elsevier: pp. 720-725. Available at: https://www.elsevier.com/.../kumar...clarksclinicalmedicine/kumar/9.accessed in July 22, 2016.

Lee J., Reyes B.A., McManus D.D., Maitas O., Chon K.H. (2013). Atrial fibrillation detection using an iPhone 4S. IEEE Trans Biomed Eng.; 60(1): pp. 203-6. Available at: https://www.ncbi.nlm.nih.gov/pubmed/22868524.Accessed in Feb5, 2017.

Martin R.I., Pogoryelova O., Koref M.S., Bourke J.P., Teare M.D., Keavney B.D. (2014). Atrial fibrillation associated with ivabradine treatment: meta-analysis of randomised controlled trials. Heart; 100: pp. 1506-1510. Available at: https://www.ncbi.nlm.nih.gov/pubmed/24951486. Accessed in august 8, 2016.

McCabe P.J. (2009). Predictors of symptom and psychological distress in patients with recurrent Symptomatic atrial fibrillation (Doctoral Dissertation). Omaha, NE: University of Nebraska Medical Center. Available at: https://www.ncbi.nlm.nih.gov/pmc/articles/PMC3215351/. Accessed in September5, 2017.

Naddaf A.R. (2004). Lifestyle of hypertensive patients and their drug compliance. Bull. Pharm. Sci., Assiut University; Vol. 27, part 2: pp.307-314. Available at: iu.edu.jo/.../pharmacy/.../CURRICULUM\%20VITAE\%20Naddaf.doc. Accessed in May, 2017. 
Smeltzer S., Bare B. (2010). Brunner \&Suddarth's: Text book of medical and surgical nursing, 10th Ed. London: Churchill Livingstone, pp.720-7. Available at: https://www.amazon.com/Suzanne-Smeltzer-Brenda.../B006VIUXYI.Accessed in May8, 2016.

Smith J.G., Platonov P.G., Hedblad B., Engstrom G., Melander O. (2010). Atrial fibrillation in the Malmo Diet and Cancer study: a study of occurrence, risk factors and diagnostic validity. Eur J Epidemiol.; 25(2): pp. 95-102. Available at: https://www.ncbi.nlm.nih.gov/pubmed/19936945. Accessed in April5, 2016.

Tang E., Lai C., Lee K. (2003). Relationship between patient warfarin knowledgese and anticoagulation control. Ann Pharm. 37: pp. 34-39. Available at: https://www.ncbi.nlm.nih.gov/pubmed/12503930. Accessed in Dec 6, 2016.

Tesha JJ. (2006). Knowledge of stroke among hypertensive patients in selected hospital in the Tanga Region, Tanzania. Master thesis. Faculty of community and health sciences. University of the Western Cape. Available at https://www.ncbi.nlm.nih.gov/pubmed/12503930. Accessed in Dec 6, 2016.

World health statistic, (2015). The Selection and Use of Essential Medicines. (Including the 19th WHO Model List of Essential Medicines). 2015, (19th, p. 311).

Xu, W., Sun, G., Lin, Z., Chen, M., Yang, B., Chen, H., \& Cao, K. (2010): Knowledgese, attitude, and behavior in patients with atrial fibrillation undergoing radiofrequency catheter ablation. Journal of Interventional Cardiology and Electrophysiology. 2010; 28, pp. 199-207. Available at: https://www.ncbi.nlm.nih.gov/pubmed/20556497. Accessed in Feb8, 2016.

Yassien A.M., Khataybeh O.Y., Aleyadeh A., Al-Kurdi N.E., AL Shawabkah T.A. (2012). Patients Experience and Knowledgese about using Coumarine and Coagulation Test. Z.U.M.J; 18(6): pp. 11181122. Available at:https://digitalcommons.usu.edu/cgi/viewcontent.cgi?article=1007. Accessed in March 8, 2018. 
Zubaid M., Rashed W.A., Alsheikh-Ali A.A., Almahmeed W., Shehab A., Sulaiman K., AlZakwani I., Alqudaimi A., Asaad N., Amin H. (2011). Characteristics of patient with atrial fibrillation in the Arab Middle East Gulf Survey of Atrial Fibrillation Events (Gulf SAFE) Investigators. Journal of Cardiovascular Quality and Outcomes; 4: $\quad$ pp. 477-482. Available at: https://www.ncbi.nlm.nih.gov/pubmed/21772004. Accessed in February 6, 2017.

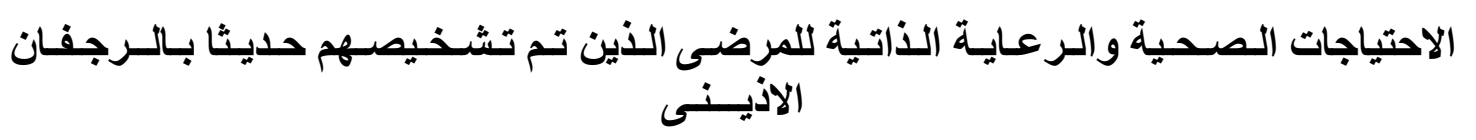

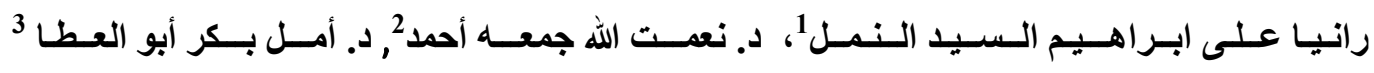

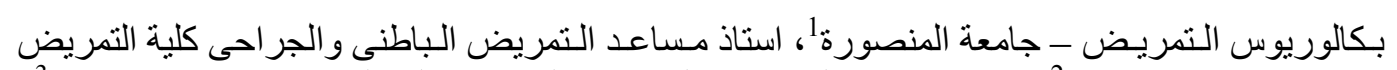

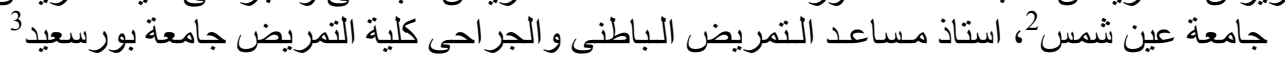

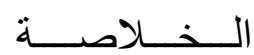

يعتبر مرض الرجفان الاذينى الاكثر انتشارا بين امراض اضطر ابا القلب الريزمى فى العالم ،لللك معرفة

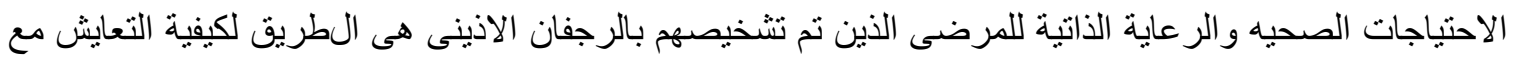
هذا المرض .صـمـت هذه الدراسـة الوصفيـة لمعرفة الاحتياجات الصحية والرعاية الذاتية لاى المرضى الذين تم تشخيصهم حديثا بالرجفان الاذينى .وقد أجريت هذه الدر اسـة على 110 مريضا من مستشفيات محافظة بورسعيد على النحو التالي: مستشفى الزهور ،مستشفى بورسعيد العام، ومستشفى التضامن .تم استخدام اثنين مـن الأدوات

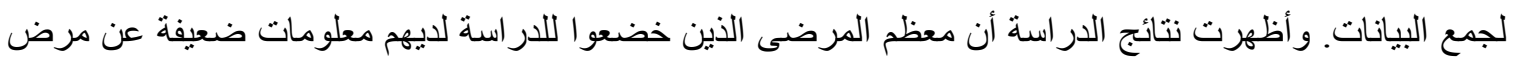
الرجفان الاذينى. وكان مستوى الرعاية الذاتيه افضل عند الذكور واصحاب مستويات التعليم الاعلى والذين يعملون وسكان المدن. وكان مستوى المعلومات مؤشر ا ايجابيا لمستوى الرعاية الذاتيه وبالتالى المرضى الذين لديهم معرفة

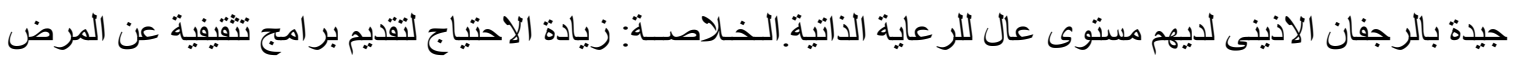
وذللك لتحفيز مرضى الرجفان الاذينى للعب دور نشط فى العلاج وكيفية الوقاية من المضاعفات ـوأوصـــ نـتـائسج

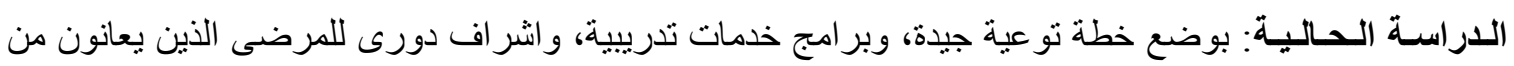
الرجفان الاذينى. 